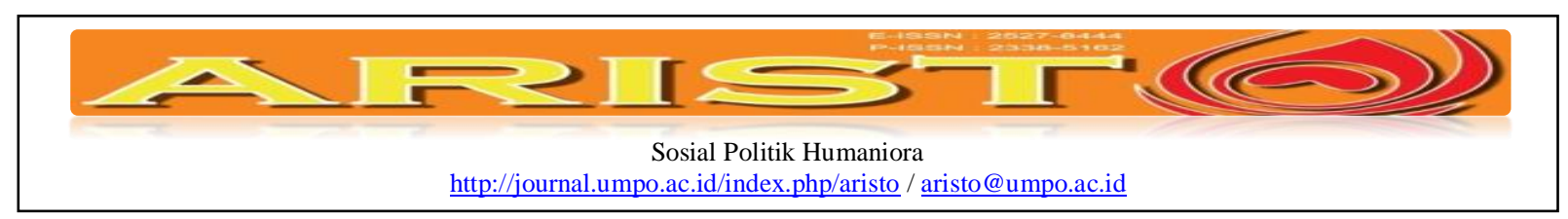

\title{
Karakteristik Gaya Komunikasi Presiden Jokowi Dalam Pengambilan Kebijakan
}

\author{
Drina Intyaswati, Mansur \\ FISIP UPN "Veteran" Jakarta \\ nanazain@gmail.com
}

\begin{abstract}
The mass media bring news about the various issues that arise in the community, including those related to communication styles of President Jokowi in communicating policies. The last case, in which ministers make "political noise" that attacked each other in front of the public, many people questioned about coordination between Jokowi and his officials. Furthermore, researchers set problems taken in the study, 1) How is the characteristic of Jokowi's communication style in communicating policies 2) How is the communication competencies possessed by Jokowi?. Research using qualitative research methods with a macrostruktural discourse analysis approach. The population are news about communications by President Jokowi, where the medium used is the online media. Online media selected in sampling are News.detik.com and Kompas.com which is the most popular news providers (version ALEXA per February 18, 2015). The results showed that the characteristic of Jokowi's communication style in communicating policies in general is controlling style, although in some situations also use communication styles in accordance with existing conditions. Based on an analysis of the communication's Jokowi in communicating policies, Jokowi's communication competence covering aspects of commitment and confidence, empathy, flexibility, senstivity of consequences, and proficiency.
\end{abstract}

Keywords: Communication Style, Jokowi, Discourse Analysis, Communication Competence

\begin{abstract}
Abstraksi
Media massa memunculkan berita tentang berbagai isu yang timbul dalam masyarakat, termasuk yang berhubungan dengan gaya komunikasi Presiden Jokowi dalam pengambilan kebijakannya. Kasus terdahulu, dimana para menterinya membuat "gaduh politik" yang saling menyerang di didepan publik, membuat banyak kalangan mempertanyakan koordinasi komunikasi Jokowi beserta jajarannya. Selanjutnya peneliti menetapkan permasalahan yang diambil dalam penelitian, yaitu : 1) Bagaimana karakteristik gaya komunikasi Jokowi dalam pengambilan kebijakannya 2) Bagaimana kompetensi komunikasi yang dimiliki oleh Jokowi ?. Penelitian menggunakan metode penelitian kualitatif dengan pendekatan analisis wacana makrostruktural. Populasi dalam penelitian ini adalah berita- berita tentang komunikasi yang dilakukan Presiden Jokowi, dimana media yang digunakan adalah mediaonline. Media online terpilih dalam pengambilan sampel adalah News.detik.com dan Kompas.com yang merupakan penyedia berita terpopuler (versi ALEXA per 18 Februari 2015). Hasil penelitian menunjukkan bahwa karakteristik gaya komunikasi Jokowi dalam pengambilan kebijakan secara umum adalah gaya mengendalikan (controlling style).Berdasar analisis terhadap komunikasi Jokowi dalam
\end{abstract}

Drina Intyaswati, Mansur, Karakteristik Gaya Komunikasi Presiden Jokowi Dalam Pengambilan Kebijakan /05/Vol. 05/No. 02 Juni 


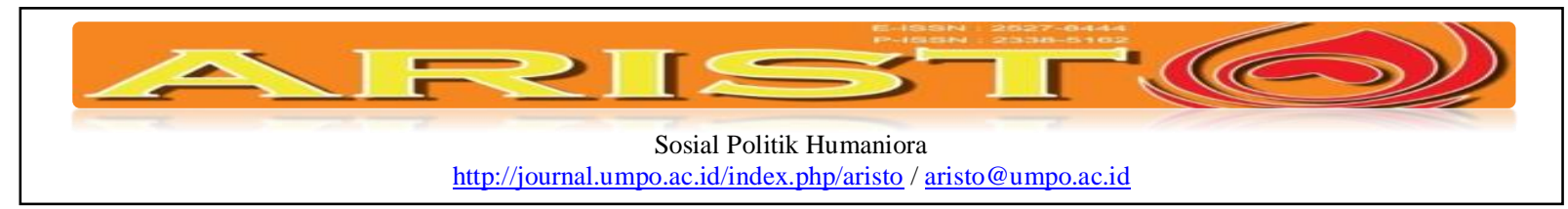

menyampaikan kebijakannya, Jokowi memiliki kompetensi komunikasi yang meliputi aspek komitmen dan keyakinan, empati, fleksibilitas, sensibilitas konsekuensi, dan kecakapan.

Kata Kunci: Gaya Komunikasi, Jokowi, Analisis Wacana, Kompetensi Komunikasi.

\begin{tabular}{|ll}
\hline Submite & $:$ 20 Jan 2017 \\
Review & $:$ 20 April 2017 \\
Accepted & $:$ 30 Mei 2017 \\
Surel Corespondensi & $:$ winda86@gmail.com \\
\hline
\end{tabular}

\section{Pendahuluan}

Komunikasi terjadi jika seeorang (komunikan) mendapatkan pesan atau informasi yang dilakukan oleh individu yang lain sedemikian hingga tingkah laku komunikan menjadi terpengaruh oleh stimulus atau rangsangan yang diterimanya. Komunikasi dapat dilakukan melalui media yang berbeda-beda. Komunikasi sendiri terdiri dari komunikasi verbal yang berupa tulisan dan lisan, serta komunikasi nonverbal, yaituterjadinya pertukaran pesan yang tanpa menggunakan lisan atau ucapan, layaknya komunikasi yang memakai gerakan badan, sikap tubuh, vokal yang tidak memiliki makna yang umum, tatapan mata, tampilan muka, dan faktor posisi. Dengan bahasa yang lain dapat dikatakan konteks yang ada di sekitar komunikasi yang tidak ada relevansinya dengan apa yang disampaikan melalui kata-kata maupun tulisan. Saat ini di berbagai media massa muncul berita tentang bagaimana berbagai isu timbul yang berhubungan dengan gaya komunikasi Presiden Jokowi dalam pengambilan kebijakan, baik kebijakan dalam negeri ataupun luar negeri, karena tampak ketidakharmonisan komunikasi khususnya dalam kabinet Presiden Jokowi. Banyak pihak yang mengemukakan pendapat bagaimana seharusnya Jokowi bersikap dalam komunikasinya.

Penelitian sebelumnya menemukan bahwa orang memiliki perbedaan dalam gaya komunikasi dipengaruhi oleh budaya yang berbeda (Sanchez-Burks et al., 2003). Indonesia sendiri terdiri dari beragam suku, di mana juga akan mempengaruhi gaya komunikasi seseorang. Berdasarkan perbedaan budaya ada istilah low-context dan high-context. Pesan eksplisit digunakan oleh orang-orang dari budaya dengan konteks rendah, mereka kurang memperhatikan informasi yang melatarbelakangi komunikasi (kontekstual), sementara orang-orang dari budaya konteks tinggi tidak bergantung pada informasi langsung dan lebih memperhatikan informasi kontekstual (Hall, 1990). Gaya komunikasi sering menggunakan dimensi eksplisit dan implisit, yang menggambarkan bagaimana pembicara mengungkapkan niat mereka melalui pesan 


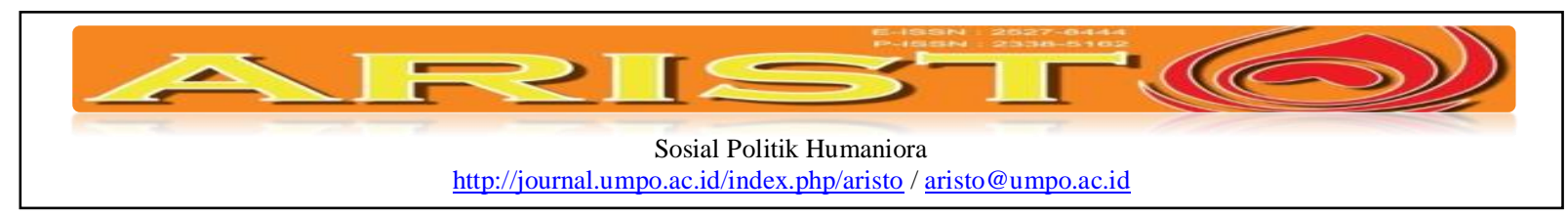

eksplisit atau pesan langsung. Gaya komunikasi yang eksplisit adalah orang yang berbicara langsung menyatakan perasaan, niat, dan keinginannya, sedangkan gaya komunikasi implisit adalah orang yang berbicara secara lisan dengan kamuflase dan menyembunyikan niat sejatinya (Gudykunst et al., 1988).Domain kompetensi komunikasi berada dalam kognitif manusia, namun muncul dalam keterampilan seseorang dalam ekspresi komunikasi verbal dan nonverbal, dan proses produk kognitif manusia ditunjukkan melalui penggunaan keterampilan ini. Mekanisme pemrosesan internal pesan komunikasi terjadi dalam kecerdasan kognitif sementara domain kognitif mencakup perilaku komunikatif.

Sebuah studi tentang kompetensi komunikasi oleh Choon (2004) menemukan bahwa kompetensi komunikasi memiliki tiga dimensi: kepercayaan diri, citra diri, dan rasa hormatrelasional. Selanjutnya Lailawati (2006) yang melihat gaya komunikasi orang Melayu berpendapat bahwa bagi orang Melayu Malaysia, agama yang mereka anut akan membentuk komunikasi mereka. Asma (1996) sebelumnya merekomendasikan bahwa para pemimpin Melayu diharapkan dapat menjadi teladan perilaku mereka berdasarkan nilai-nilai agama dan budaya bawahan mereka, dalam upaya untuk memenangkan hati dan pikiran mereka. Dapat dikatakan bahwa kelayakan kompetensi komunikasi berdasar pada kontekstual, situasional, dan batasan budaya. Masalah perilaku komunikatif yang tepat berbeda dari satu situasi dan situasi lainnya. Namun, seberapa baik seseorang dapat menggunakan kemampuan dalam konteks atau situasi yang berbeda akan mempengaruhi perilaku yang sesuai.

Saat ini dalam media massa muncul kabar tentang bagaimana berbagai isu yang diangkat terkait dengan gaya komunikasi Presiden Jokowi dalam pembuatan kebijakan, baik dalam kebijakan dalam negeri maupun luar negeri, karena terlihat komunikasi tidak harmonis terutama di kabinet Presiden Jokowi. Banyak dari mereka yang menyatakan pendapatnya bagaimana Jokowi harus bersikap dalam komunikasinya. Berdasar pada berita - berita yang muncul maka dirumuskan masalah dalam penelitian ini adalah ; (1) bagaimana karakteristik gaya komunikasi Presiden Jokowi dalam pengambilan. (2) bagaimana kompetensi komunikasi yang dimilki Presiden Jokowi. Dengan dilakukanya penelitian ini diharapkan dapat diketahui bagaimana karakteristik gaya komunikasi Presiden Jokowi dalam mengkomunikasikan kebijakannya, baik kebijakan dalam negeri maupun luar negeri, serta mengetahui bagaimana kompetensi komunikasinya.

Drina Intyaswati, Mansur, Karakteristik Gaya Komunikasi Presiden Jokowi Dalam Pengambilan Kebijakan /05/Vol. 05/No. 02 Juni 


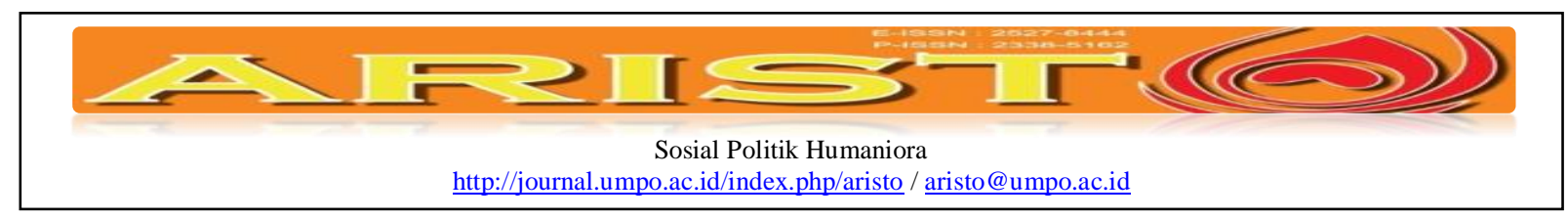

Dalam cara berpikir yang kritis pemahaman tentang wacana adalah bagaimana bahasa digunakan dalam praktek sosial. Pemahaman wacana harus dipahami sebagai satu kesatuan dari tiga dimensi yang membahas tentang wacana itu sendiri; wacana, teks, dan praktek sosial kultural (Jufri,2008:22). Dimensi teks meliputi bahasa lisan dan tulisan, dimensi praktek wacana berhubungan dengan bagaimana memproduksi dan intepretasi teks, dan dimensi praktek sosial kultural berkaitan dengan perubahan aspek sosial kemasyarakatan, kelembagaan, dan sistem budaya yang berlaku, ketiga hal tersebut turut memberikan arah bagaimana bentuk dan pemaknaan dari suatu wacana.Analisis wacana itu mengkaji hubungan bahasa dengan kontekspenggunaannya. Untuk memahami sebuah wacana perlu diperhatikan semuaunsur yang terlibat dalam penggunaan bahasa tersebut. (Arifin \& Rani, 2000 : 14). Secara makrostruktural, analisis wacana lebih menekankan pada gambaran umum darisusunan wacana itu secara global untuk memahami teks secara keseluruhan.Disamping memperhatikan keterkaitan antarepisode dan paragraf, jugadipertimbangkan bagaimanan latar belakang dan pandangan kedepannya. Pendekatan makrostruktural mencakup konteks, leksis, dan struktur tekstual,yang dimaksudkan konteks secara makrostrukturaladalah konteks situasi dan budaya (Sumarlam, 2003 : 195).

\section{Metode dan Kajian Pustaka}

Jenis penelitian yang digunakan adalah penelitian kualitatif dengan pendekatan analisis wacana makrostruktural. Populasi dalam penelitian ini adalah berita- berita tentang komunikasi yang dilakukan Presiden Jokowi baik yang menyangkut kebijakan dalam negeri maupun luar negeri, dimana media yang digunakan adalah media online. Pengambilan sampel menggunakan metode judgement sampling, dengan sampel terpilih yaitu berita yang diambil dari News.detik.com dan Kompas.com yang merupakan dua peringkat pertama penyedia berita terpopuler (versi ALEXA per 18 Februari 2015). Pengambilan data dilakukan selama JanuariFebruari 2017.

\section{Gaya Komunikasi}

Gaya komunikasi (communication style) dapat dipahami sebagai serangkaian dari bagaimana seseorang berperilaku dengan orang lain yang terspesialisasi digunakan dalamsuatu situasi tertentu. Gaya dapat dipahami sebagai penggunaan kata-kata atau verbal maupun nonverbal yang dapat berupa bahasa tubuh, vokalik, penggunaan ruang, penggunaan waktu dan

Drina Intyaswati, Mansur, Karakteristik Gaya Komunikasi Presiden Jokowi Dalam Pengambilan Kebijakan /05/Vol. 05/No. 02 Juni 


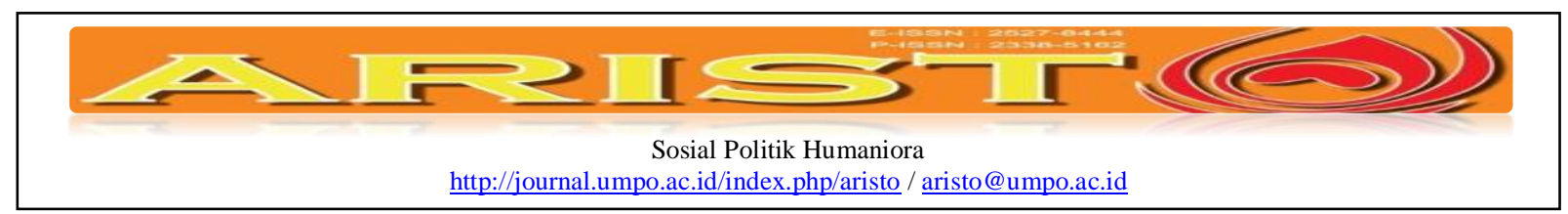

jarak (Widjaja,2000: 57). Sedangkan gaya Komunikasi yang akan kita jadikan acuhan dalampenelitian ini adalah sebagai berikut (Hariyana, 2009:14-18) : 1) The Controlling Style, komunikatormemiliki kecenderungan berkomunikasi dengan sifat mengendalikan, dengan maksud untuk mengatur pikiran, tangggapan, dan perilaku orang lain. 2) The Equalitarian Style, komunikator berkomunikasi secara terbuka sehingga terjadi interaksi dua arah antara pengirim dan penerima pesan, gaya komunikasi ini ditandai adanya landasan kesamaan. 3) The Structuring Style,komunikator menyampaikan pesan dengan maksud sesuatu yang sudah terstruktur bisa dilaksanakan sesuai dengan ketentuan yang ada. 4) The Dynamic Style, komunikator menyampaikan pesan agar sesuatu hal bisa dikerjakan lebih efektif dan cepat. 5) The Relinguishing Style, komunikator menyampaikan pesan kepada penerima pesan yang memiliki pengetahuan yang luas sehingga komunikator bisa menerima gagasan atau umpan balik yang diterima. 6) The Withdrawal Style, komunikator memiliki masalah atau kesulitan dalam berkomunikasi antar pribadi, sehingga cenderung tidak mau untuk berkomunikasi.

\section{Kompetensi Komunikasi}

Kompetensi komunikasi merupakan kemampuan seseorang dalam menyampaikan pesan dan menunjukkan bagaimanan tujuan akan dicapai,dimana komunikasi tersebut disampaikan kepada khalayak (Rowley, 1999). Komunikator berusahamenselaraskankan komunikasi yang terjadi sehingga mendapatkaninteraksi komunikasi yang produktif, mulus, dan akan menyenangkan. Kompetensi ini merupakan kemampuan dan cara bersikap yang perlu dimiliki, meliputi: (1) Keyakinan serta komitmen (Good faith and commitment), (2) Empathy: kemampuan yang dimiliki untuk dapat memahami situasi dari cara pandang orang lain. (3) Flexibility: kemampuan komunikator untuk menyesuaikan danmengembangkan berbagai kemampuan komunikasi. (4) Sensitivitas untuk konsekuensi : pemilihan komunikasi kemungkinan memberikan keberhasilanpada suatu kondisi tertentu dan ketidakberhasilan dalam kondisi yang berbeda. Berdasar penelitian sebelumnya, kompetensi komunikasi akan mendapatkan kecakapan yang lebih baikjika dapat menangani gangguan yang ada dengan menggunakan bermacam keterampilan mengatasi situasi yang rumit. (5) Adeptness: dengan pengalaman yang kita miliki, kita akan lebih memilki kecakapan. Efektifitas komunikasi sebagian dihubungkan dengan bagaimana kita meresponnya secara spontan. Dapat 


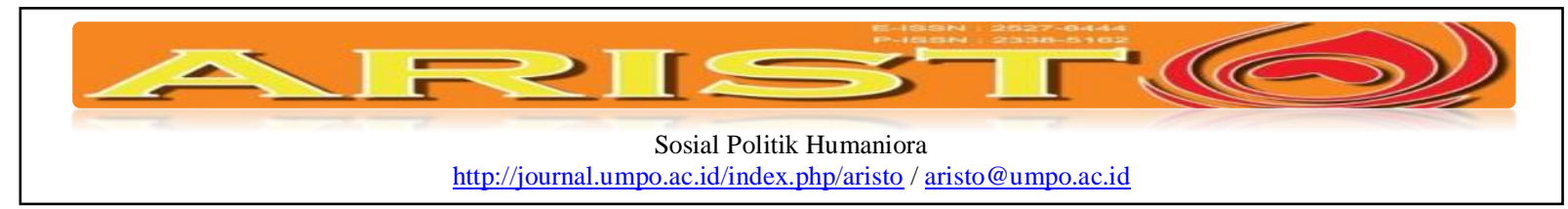

mengintegrasikan pilihan-kata, waktu, ritma, dan penekanan dengan baik dan dilakukan secara natural, maka keterampilan komunikasi akan didapatkan.

\section{Komunikasi Internasional}

Komunikasi internasional merupakan bidang ilmu yang memfokuskan kajiannya pada proses aliran informasi dan data secara keseluruhan yang melintasi batas antar negara. Yang menjadi kajian telaah tidak hanya arus informasi dan data, juga melihat bagaimana struktur arus yang dihasilkan, personal yang ikut di dalamnya, penggunaan sarana, efek yang terjadi, serta dasar motivasi yang menjadi acuan. Pendekatannya bersifat makro, dengan unit analisanya adalah aktor-aktor yang bersifat non-individual, dan kajiannya berkaitan dengan wilayah kajian ilmu hubungan internasional dan juga ilmuekonomi politik internasional. Kajian komunikasi internasional lebih melihat interaksi dipengaruhi oleh kepentingan negara yang melahirkan kebijaksanaan untuk memenuhi kepentingan tersebut. Selanjutnya bentuk komunikasi yang dilakukan antar bangsa lebih mengarah kepada hubungan yang bersifat politik yang nantinya dikembangkan ke hubungan di bidang lainnya. Mengkaji komunikasi internasional dapat dimudahkan dengan membaginya dalam tiga perspektif yaitu perspektif, jurnalistik, diplomatik, dan propagandistik.

\section{Pembahasan dan Analisis}

Berdasar analisis berita-berita tentang Jokowi di News.detik.com dan Kompas.com diperoleh hasil sebagai berikut :

\section{1) Isu Status hukum Ahok}

Berdasar berita detikNews selasa 14 Februari 2017 dengan judul "Jokowi Perintahkan Mendagri Konsultasi ke MA Soal Status Ahok". "Oleh Pak Jokowi (Mendagri) diperintah untuk konsultasi ke MA. Besok pagi pak Menteri akan konsultasi dengan MA sebelum menghadiri ratas dengan presiden RI," kata Kapuspen Kemendagri, Dodi Riyatmadji. Dalam berita ini tidak dicantumkan pernyataan Jokowi secara langsung.

\section{2) Isu penyadapan telepon SBY}

Berdasar berita detikNews rabu 1 Februari 2017 dengan judul "Seskab: Pemerintah Tak Pernah Instruksikan Penyadapan SBY”, pemerintah dalam hal ini presiden Jokowi melalui Sekretaris kabinet Pramono Anung menyatakan, bahwa yang jelas dalam isu tersebut tidak pernah ada 


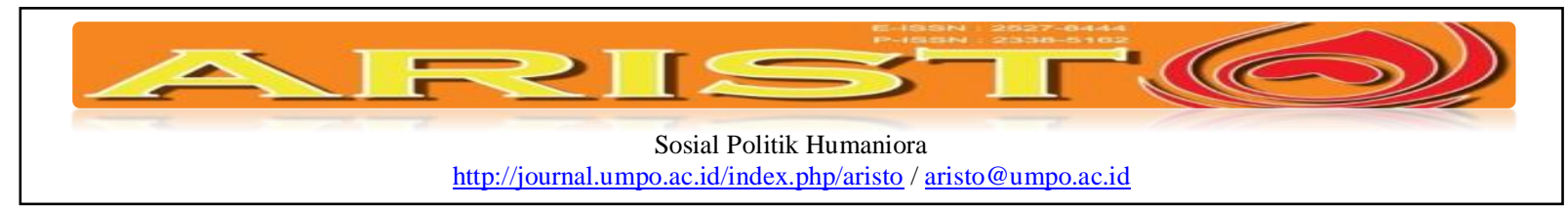

instruksi atau permintaan penyadapan yang ditujukan kepada SBY. Topik kasus ini juga diangkat oleh kompas.com pada tanggal 9 Februari 2017 dengan judul "SBY Bertanya, Jokowi Menjawab...”. Jokowi di sela sela perjalanannya di pusat perbelanjaan yang banyak dikunjungi masyarakat di Kota Ambon sempat memberi pernyataan dengan sambil bergurau, menurut Jokowi semua sekarang ditanyakan kepada Kapolri dan Presiden. Begitu banyak pertanyaan yang menyangkut segala hal. Selanjutnya Jokowi mempertanyakan kepada siapa dia bisa bertanya. Pernyataan lanjutannya, Jokowimenyatakan akan lebih baik jika hal-hal yang berhubungan dengan masalah negara di bicarakan atau dimusyawarahkan dalam forum tertentu yang kemudian dicarikan penyelesaiannya dan masyarakat mengetahui hasilnya, cara seperti itu akan lebih baik.

\section{3) Isu tertangkapnya Hakim Mahkamah Konstitusi oleh KPK}

Berdasar berita detikNews selasa 31 Januari 2017 dengan judul "Jokowi Ingin Pansel MK Terbuka agar Kasus Patrialis Tak Terulang”, Sekretaris kabinet Pramono Anung atas nama pemerintah menyatakan bahwa Presiden Jokowi ingin agar proses pemilihan hakim konstitusi pengganti Patrialis Akbar, yang tertangkap tangan oleh KPK, dilakukan secara terbuka. Topik kasus ini juga diangkat oleh kompas.com pada tanggal 28 Januari 2017 dengan judul yang agak provokatif yang dipilih oleh penulis “Tidak seperti SBY, Ini Cara Jokowi Angkat Hakim MK Pengganti Patrialis”. Penulis juga menambahkan bahwa pengangkatan Patrialis Akbar sebagai Hakim MK pada tahun 2013 lalu, menggunakan cara penunjukan langsung yang merupakan hak SBY selaku presiden waktu itu, dan sekarang Jokowi akan mencari orang sebagai pengganti Patrialis melalui cara yang terbuka dan terukur

\section{4) Isu komunikasi hasil kerja kepada publik}

Berdasar berita detikNews rabul Februari 2017 dengan judul "Jokowi: Kerja Keras Kita Perlu Diketahui Rakyat", presiden Jokowi menyatakan melalui sidang kabinet paripurna yang dipimpinnya bahwa apa yang telah dicapai pemerintahan melalui kinerja yang dilakukan perlu diinformasikan kepada masyarakat. Jokowi juga meminta kepada semua jajaran menteri dan lembaga terkait untuk meningkatkan kegiatan komunikasi publik, Jokowi menyatakan bahwa dia sudah berulang kali meminta hal tersebut dilakukan, Jokowi. juga menambahkan jangan sampai pemerintah sudah bekerja keras sampai pagi, tetapi 


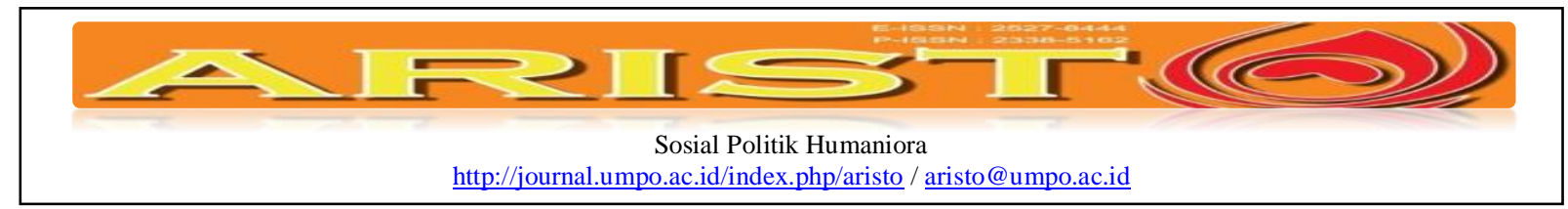

masyarakat tidak mengetahui apa yang sudah dilakukan. Topik berita ini juga diangkat oleh kompas.com pada rabu 1 Februari 2017 dengan judul "Jokowi Minta Johan Budi Beri Arahan ke Menteri soal Komunikasi Publik."Johan Budi mendapat kesempatan berbicara diakhir rapat kabinet untuk memberi arahan sesuai judul yang diambil.

\section{5) Isu Hak Asasi Manusia}

Berdasar berita detikNews jumat 10 Februari 2017 dengan judul "Sumarsih Akan Terus Menagih Janji Kampanye Jokowi”. Berdasar pada apa yang tertera pada Nawacita disitu tercatat bahwa Jokowi-JK memiliki komitmen menyelesaikan kasus-kasus tentang pelanggaran HAM yang terjadi di masa lalu secara adil. Dalam tulisan tersebut tidak ada kutipan langsung dari pernyataan Jokowi tentang penyelesaian kasus HAM, akan tetapi apa yang dirasakan Sumarsih dan keluarga korban HAM adalah tidak ada kemauan Jokowi untuk berkomunikasi dengan mereka.

\section{6) Isu Terorisme}

Berdasar berita detikNews jumat 10 Februari 2017 dengan judul "Kumpulkan Jajaran TNI dan Polri, Jokowi: Terorisme Harus Dicegah”. Presiden Jokowi telah mengumpulkan Babinsa serta Babinkamtibmas di Jawa Tengah, tepatnya di kota Solo. Menurut Jokowi jika informasi yang disampaikan dari atas bisa diterima di bawah secara utuh maka pesan dari atas akan bisa dimengerti semuanya dan dilakukan oleh yang dibawah seperti yang diharapkan. Karena itu, pertemuan tersebut dilakukan agar melalui penyampaian langsung pesan yang disampaikan bisa diterima secara utuh.

\section{7) Isu Harmonisasi Menhan-Panglima TNI}

Berdasar berita kompas.com rabu 8 Februari 2017 dengan judul "Bantah JK, Jokowi Mengaku Belum Instruksikan Harmonisasi Menhan - Panglima TNI". Presiden Jokowi menyatakan bahwa pernyataan Jusuf Kalla tentang adanya perintah presiden agar dilaksanakan harmonisasi antara Panglima TNI Jendral Gatot Nurmayanto dan Menteri Pertahanan Indonesia Ryamizard Ryacudu belum dilakukan.

\section{8) Isu Kebijakan Donald Trumph}

Berdasar berita kompas.com rabu 30 Januari 2017 dengan judul "Jokowi menyatakan soal Kebijakan Anti - imigran Donald Trump", Presiden Joko Widodo merespons kebijakan Presiden AS Donald Trump dengan menyatakan "Prinsip konstitusi saya sudah jelas, yang 


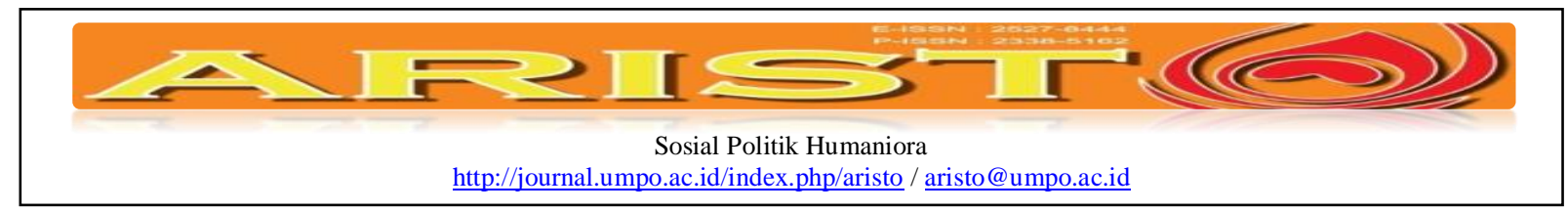

namanya kesetaraan, dan juga keadilan harus tetap diperjuangkan". Meski demikian, Jokowi yakin kebijakan yang kontroversial itu tidak akan memberikan efek bagi rakyat dan warga negara Indonesia. "Kita tidak terkena dampak dari kebijakan itu, kenapa resah?" ujar Jokowi.

\section{9) Isu Bantuan untuk negara tetangga}

Berdasar berita kompas.com rabu 1 Januari 2017 dengan judul "Jokowi Lepas 10 Kontainer Bantuan untuk Warga Rohingya". Pemerintah Indonesia mengirimkan paket bantuan kemanusiaan kepada warga Rohingya yang berada di Rakhine State, Myanmar. Bantuan tersebut merupakan bentuk hubungan diplomasi kemanusiaan dimana Indonesia berkontribusi pada negara-negara di dunia "Segera akan kami berangkatkan 10 kontainer barang-barang yang akan dikirim ke Myanmar untuk membantu saudara-saudara kita di Rakhine State, khususnya komunitas Muslim," ujar Jokowi. Terdapat isu yang serupa berdasar berita detik.com selasa 14 Februari 2017 dengan judul "Kirim Lima Ribu Ton Beras, Menlu: Bentuk Persahabatan Sri Lanka - RI.”.Presiden Jokowipernah mengatakan bahwa bantuan yang diberikan adalah permintaan langsung dari Presiden Sri Lanka yang bernama Maithripala Sirisena melaluiKedutaan Besar Sri Lanka di Jakarta. Indonesia sebagai sahabat dan juga sebagai negara besar di kawasan Asia, sudah selayaknya terlibat membantu mengirimkan bantuan. Jokowi menyatakan cepat merespon permintaan bantuan tersebut, karena situasi di sana memang sangat memerlukan bantuan, dan telah meminta menteri yang terkait untuk mempersiapkannya. "Alhamdulillah kita bisa berangkatkan," kata Jokowi.

\section{0) Isu Freeport}

Berdasar berita kompas.com rabu 23 Februari 2017 dengan judul "Jokowi: Kalau Freeport Sulit Diajak Berunding, Saya Akan Bersikap".Jokowi menyatakan bahwa proses perundingan antara Freeport dan pemerintah masih terus berjalan,proses negosiasi masih berlangsung dan Jokowi menyerahkannya urusan tersebut kepada menteri terkait. Untuk saat ini menteri saja dulu yang menanganinya. Pada dasarnya, Pemerintah Indonesia mengharapkan adanya solusi yang berimbang, tidak ada yang dirugikan.Jokowi mengharapkan solusi yang win-win,karena ini masalah bisnis.Jokowi menyatakan jika pihak Freeport susah untuk diajak berunding, musyawarah, atau diskusi, maka Jokowi akan bersikap, ditegaskan kembali apa yang sudah pernah dinyataan. Sedangkan PT 


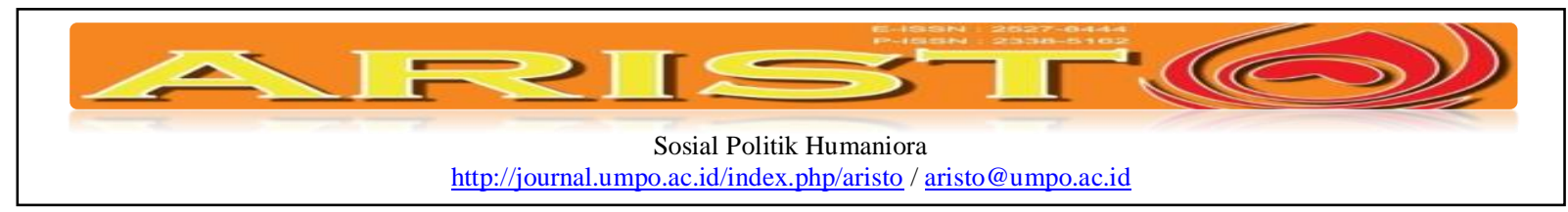

Freeport Indonesia memberi peryataan bahwa mereka tidak dapat menerima apa yang menjadi syarat-syarat yang diajukan oleh pemerintah Indonesia, mereka akan tetap berpegang teguh kepada status Kontrak Karya (KK). Jika terjadi sengketa dan tidak ada jalan keluar maka akan diselesaikan di Mahkamah Arbitrase Internasional. Persoalan ini dimulai ketikapemerintah mengumumkan adanya perubahan status operasi PT. Freeport dari awal status KK berubah menjadi status Izin Usaha Pertambangan Khusus (IUPK) yang dikeluarkan pada 10 Februari 2017. Adanya perbedaan antara kedua status operasi tersebut terletak pada posisi negara dengan perusahaan adalah setara dalam ketentuan KK, sedangkan posisi pemerintah sebagai perwakilan negara lebih tinggi selaku yang memberi izindalam IUPK,saham perusahaan juga wajib dilepaskan sedikitnya 51 persen untuk dimilikiswasta nasional atau pemerintah Indonesia. Dilihat dari Peraturan Pemerintah Nomor 1 Tahun 2017, yang bisa melakukan ekspor konsentrathanyalah perusahaan pemegang IUPK.

Tabel 1. Ringkasan Analisis Wacana Makrostruktural

\begin{tabular}{|c|c|c|c|}
\hline ISU & $\begin{array}{c}\text { SISTEM LEKSIS } \\
\text { (PEMILIHAN KATA) }\end{array}$ & $\begin{array}{c}\text { KONTEKS } \\
\text { (SITUASI - BUDAYA })\end{array}$ & $\begin{array}{c}\text { GAYA KOMUNIKASI } \\
\text { JOKOWI }\end{array}$ \\
\hline $\begin{array}{l}\text { Status hukum } \\
\text { Ahok }\end{array}$ & $\begin{array}{l}\text { Jokowi Perintahkan Mendagri } \\
\text { Konsultasi ke MA }\end{array}$ & $\begin{array}{l}\text { Terdapat perbedaan } \\
\text { pendapat ahli hukum }\end{array}$ & $\begin{array}{l}\text { Mengendalikan } \quad \text { (controlling } \\
\text { style) }\end{array}$ \\
\hline $\begin{array}{l}\text { Penyadapan } \\
\text { telepon SBY }\end{array}$ & $\begin{array}{l}\text { Pemerintah Tak Pernah } \\
\text { Instruksikan Penyadapan SBY }\end{array}$ & $\begin{array}{l}\text { Beredar isu penyada-pan } \\
\text { telepon SBY }\end{array}$ & $\begin{array}{l}\text { Mengendalikan } \quad \text { (controlling } \\
\text { style) }\end{array}$ \\
\hline & $\begin{array}{l}\text { SBY Bertanya, Jokowi } \\
\text { Menjawab }\end{array}$ & $\begin{array}{l}\text { Pertanyaan SBY kepada } \\
\text { Jokowi-Kapolri melaui } \\
\text { twitternya }\end{array}$ & Dinamis (dinamic style) \\
\hline $\begin{array}{l}\text { Tertangkapnya } \\
\text { hakim MK } \\
\text { oleh KPK }\end{array}$ & $\begin{array}{llll}\text { Jokowi Ingin } & \text { Pansel } & \text { MK } \\
\text { Terbuka } & & & \end{array}$ & $\begin{array}{l}\text { Proses pemilihan hakim } \\
\text { MK dipertanyakan }\end{array}$ & $\begin{array}{l}\text { Menerima saran atau gagasan } \\
\text { orang lain (relinguishing style). } \\
\text { Mengendalikan (controlling } \\
\text { style }\end{array}$ \\
\hline \multirow{3}{*}{$\begin{array}{l}\text { Komunikasi } \\
\text { hasil kerja } \\
\text { kepada publik }\end{array}$} & $\begin{array}{l}\text { Tidak seperti SBY, Ini Cara } \\
\text { Jokowi Angkat Hakim MK }\end{array}$ & $\begin{array}{l}\text { Proses pemilihan hakim } \\
\text { MK }\end{array}$ & $\begin{array}{l}\text { Mengendalikan } \\
\text { style }\end{array}$ \\
\hline & 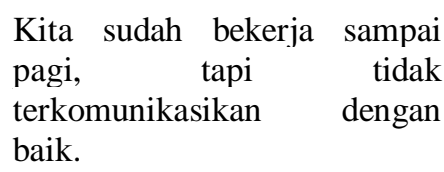 & $\begin{array}{l}\text { Kebututuhan partisipasi } \\
\text { publik terhadap program } \\
\text { pemerintah }\end{array}$ & $\begin{array}{l}\text { Landasan kesamaan (egalitarian } \\
\text { style }\end{array}$ \\
\hline & $\begin{array}{l}\text { Nanti saya minta } 5 \text { menit Juru } \\
\text { Bicara }\end{array}$ & $\begin{array}{l}\text { Efektivitas komunikasi } \\
\text { antar kementrian - }\end{array}$ & $\begin{array}{l}\text { Tidak ada kemauan untuk } \\
\text { berkomunikasi } \\
\text { style) }\end{array}$ \\
\hline
\end{tabular}

Drina Intyaswati, Mansur, Karakteristik Gaya Komunikasi Presiden Jokowi Dalam Pengambilan Kebijakan /05/Vol. 05/No. 02 Juni 


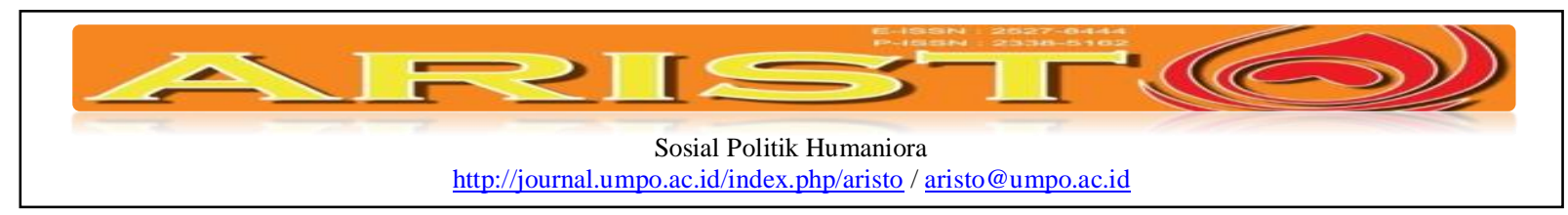

\begin{tabular}{|c|c|c|c|c|}
\hline & menyampaikan di akhir & lembaga & & \\
\hline HAM & 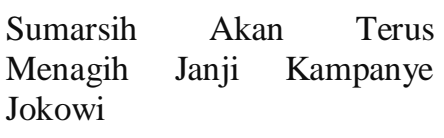 & $\begin{array}{l}\text { Penyelesaian } \\
\text { HAM terdahulu }\end{array}$ & $\begin{array}{l}\text { Mengendalikan } \\
\text { style) }\end{array}$ & (controlling \\
\hline Terorisme & $\begin{array}{l}\text { Kumpulkan Jajaran TNI dan } \\
\text { Polri, Jokowi: Terorisme Harus } \\
\text { Dicegah }\end{array}$ & Pencegahan terorisme & $\begin{array}{l}\text { Mengendalikan } \\
\text { style) }\end{array}$ & (controlling \\
\hline $\begin{array}{l}\text { Harmonisasi } \\
\text { Menham - } \\
\text { Panglima TNI }\end{array}$ & $\begin{array}{lr}\text { Bantah JK, Jokowi Mengaku } \\
\text { Belum } & \text { Instruksikan } \\
\text { Harmonisasi } & \text { Menhan- } \\
\text { Panglima TNI } & \end{array}$ & $\begin{array}{l}\text { Kisruh pembelian } \\
\text { helikopter Agusta } \\
\text { Westland AW101 }\end{array}$ & $\begin{array}{l}\text { Mengendalikan } \\
\text { style) }\end{array}$ & (controlling \\
\hline $\begin{array}{l}\text { Kebijakan } \\
\text { Anti-imigran } \\
\text { Donald Trump }\end{array}$ & $\begin{array}{l}\text { Kata Jokowi soal Kebijakan } \\
\text { Anti-imigran Donald Trump }\end{array}$ & $\begin{array}{l}\text { Kontroversi kebijakan } \\
\text { Donald Trump }\end{array}$ & $\begin{array}{l}\text { Mengendalikan } \\
\text { style) }\end{array}$ & (controlling \\
\hline $\begin{array}{l}\text { Bantuan untuk } \\
\text { negara } \\
\text { tetangga }\end{array}$ & $\begin{array}{llr}\text { Permintaan tersebut } & \text { secara } \\
\text { cepat saya respons } & \text { karena } \\
\text { kondisinya } & & \text { sangat } \\
\text { memerlukan sekali } & \end{array}$ & Diplomasi kemanusiaan & $\begin{array}{l}\text { Mengendalikan } \\
\text { style) }\end{array}$ & (controlling \\
\hline Freeport & $\begin{array}{l}\text { Kita ingin dicarikan solusi } \\
\text { yang menang-menang, solusi } \\
\text { yang win-win......". }\end{array}$ & $\begin{array}{l}\text { Perdebatan pergantian } \\
\text { bentuk ijin } \begin{array}{l}\text { operasi } \\
\text { Freeport }\end{array}\end{array}$ & & \\
\hline
\end{tabular}

Hasil penelitian yang diperoleh dikaitkan dengan permasalahan yang diambil yaitu ingin mengetahui karakteristik gaya komunikasi Jokowi, diperoleh bahwa gaya komunikasi yang sering digunakan oleh Jokowi adalah gaya komunikasi yang bersifat mengendalikan (controlling style). Hal ini bisa dipahami bahwa selaku presiden dalam pengambilan kebijakan pada berbagai situasi keadaan Jokowi harus bisa mengendalikan situasi, dimana hal tersebut di manifestasikan dalam berkomunikasi. Akan tetapi selain gaya mengendalikan, Jokowi juga menggunakan gaya komunikasi yang lain yaitu dinamis (dinamic style), pada penggunaan gaya ini Jokowi bisa mengubah jenis penggunaan kata-kata dalam pernyataannya dengan memperhatikan situasi dan kondisi yang ada, misalkan pernyataan yang awalnya dimulai dengan kata-kata yang bersifat gurauan (guyonan) beralih pada pengggunaan kata yang formal. Gaya komunikasi lainnya digunakan jenis yang sifatnya mau menerima saran atau gagasan orang lain (relinguishing style), jenis ini memungkinkan Jokowi mengkomunikasikan kebijakannya berdasar pertimbangan atau 


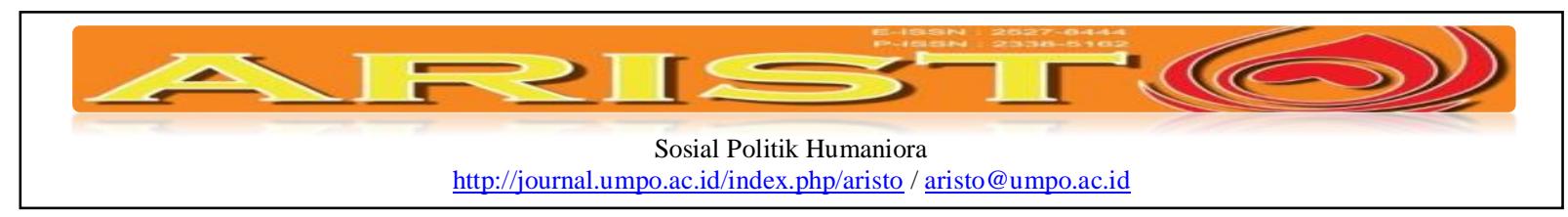

masukan dari orang-orang disekitarnya, juga Gaya komunikasi landasan kesamaan (egalitarian style) dimana Jokowi memberi kesempatan oarng lain untuk menggantikannya dalam kesempatan berkomunikasi. Gaya komunikasi yang juga digunakan oleh Jokowi adalah jenis yang sifatnya ketidakmauan atau keengganan untuk berkomunikasi (withdrawal style). Gaya komunikasi ini digunakan bila Jokowi harus menanggapi tentang kebijakan yang belum dapat diselesaikannya, misalkan kasus HAM.

Permasalahan lainnnya dalam penelitian ini adalah bagaimana kompetensi komunikasi yang dimiliki Jokowi. Kompetensi komunikasi adalah kemampuan menyampaikan berita dan mempromosikan pencapaian tujuan secara sosial (Richard D. Rowley ; 1999).Berdasar pernyataan-pernyataan yang disampaikan dalam mengkomunikasikan kebijakannya, kompetensi komunikasi dapat dilihat dari sikap, yang meliputi : komitmen dan keyakinan, empati, fleksibilitas, sensibilitas konsekuensi, dan kecakapan. Sebagian besar gaya komunikasi Jokowi bersifat mengendalikan, hal ini berarti sudah memiliki kompetensi sikap yakin dan berkomitmen, contoh dalam isu bantuan untuk negara tetangga Jokowi yakin dengan kebijakan diplomasi kemanusiaan yang diwujudkan dengan bantuan kemanusiaan berupa pengiriman bantuan beras, bantuan ini juga merupakan wujud dari sikap berempati terhadap rakyat negara srilangka dan myanmar, contoh lainnya adalah dalam isu Freeport. Kompetensi fleksibilitas terlihat pada pernyataan di kasus penyadapan telpon SBY, disana Jokowi bisa merubah gaya komunikasi yang pada awalnya berupa gurauan dilanjutnya dengan pernyataan yang formal. Kompetensi lainnya adalah sensibilitas konsekuensi, pada kasus status hukum Ahok Jokowi menyerahkannya kepada MA keputusan tentang pemberhentian Ahok sebagai gubernur, penyerahan tersebut dengan segala resikonya yang tentunya Jokowi siap menerimanya. Kompetensi terakhir adalah kecakapan, Jokowi punya cukup kecakapan dalam berkomunikasi, dapat dilihat pada kasus Harmonisasi Menham - Panglima TNI. Pada kasus itu Jokowi berusaha untuk bisa meredam ketidak harmonisam antara jajaran dibawahnya. Sehingga dapat dilihat bahwa Jokowi memiliki kompetensi komunikasi yang meliputi aspek komitmen dan keyakinan, empati, fleksibilitas, sensibilitas konsekuensi, dan kecakapan. 


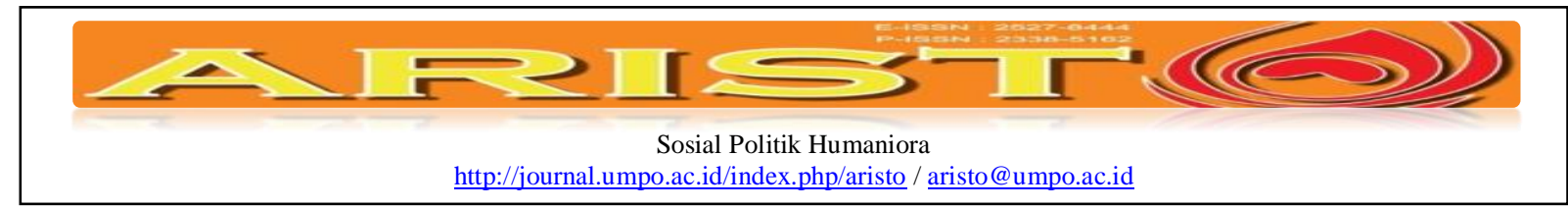

\section{Kesimpulan}

Berdasar pembahasan diatas dapat diambil kesimpulan bahwa karakteristik gaya komunikasi Jokowi dalam pengambilan kebijakan secara umum adalah gaya mengendalikan (controlling style), meskipun di beberapa situasi juga menggunakan gaya komunikasi sesuai dengan kondisi yang ada, seperti gaya komunikasi dinamis (dinamic style), menerima saran atau pendapat orang lain (relinguishing style), adanya landasan kesamaaan dalam berkomunikasi (egalitarian style) dan juga tidak ada kemauan berkomunikasi (withdrawal style). Berdasar analisis terhadap komunikasi Jokowi dalam menyampaikan kebijakannya, Jokowi memiliki kompetensi komunikasi yang meliputi aspek komitmen dan keyakinan, empati, fleksibilitas, sensibilitas konsekuensi, dan kecakapan. 


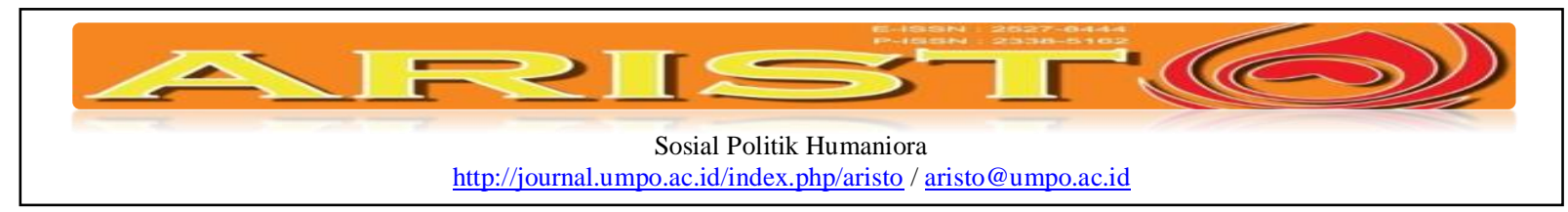

\section{DAFTAR PUSTAKA}

Asma, Abdullah. (1996). Going Global : Cultural dimensions in Malaysian Management. Kuala Lumpur. Malaysian Institute of Management.

Choon, Mooi,Choa.(2004). The Malaysian Communication Competence Construct. Journal of Intercultural Communication Research, 33, 131-146.

Dewi, Fitriana, Utami. (2011). Urgensi Komunikasi Cerdas Dalam Birokrasi Publik. Jurnal Ilmu Komunikasi, 1(1).

Gudykunst, W. B. \& Ting-Toomey, S. (1988).Culture and Interpersonal Communication. Newbury Park, CA: Sage Publications.

Hall, E. T. \& Hall, M. R. (1990). Understanding Cultural Differences: Germans, French, and Americans. Yarmouth, ME: Intercultural Press.

Hariyana, et.al,. (2009). Komunikasi Dalam Organisasi, Makalah Fakultas Ilmu Sosial dan Politik Universitas Indonesia.

Indrawan, M.Isa. (2009). Pengaruh Kompetensi Komunikasi dan Gaya Kepemimpinan Terhadap Kinerja SDM. Jurnal Ilmiah Abdi Ilmu, Vol.2 No.1. ISSN: 1979-5408.

Jufri. (2008). Analisis Wacana Kritis. Makassar. Badan Penerbit UNM.

Effendi, Onong, Uchjana. (2005). Ilmu Komunikasi: Teori dan Praktek. Bandung. PT. Remaja Rosdakarya.

Richard, D. Rowley. (1999). Communicative Competence and Interpersonal Control. In M. L. Knapp \& G. R. Miller (Eds), Handbook of Interpersonal Communication (2nd ed) (pp. 589618). Thousand Oaks, CA: Sage.

Sanchez-Burks, Jeffrey, Lee Fiona, Nisbett, Richard, Choi, Incheol, Zhao, Shuming, \& Koo, Jasook. (2003). Conversing Across Cultures: East-West Communication Styles in Work and Nonwork Contexts. Journal of Personality and Social Psychology, 85(2), 363-372.

Sumarlam. (2009). Analisis Wacana. Surakarta. Pustaka Cakra. 